\title{
Optimization of Process Parameter by using CNC Wire Electrical Discharge Machine through Taguchi Method
}

\author{
Pankaj Sharma, M. P. Singh
}

\begin{abstract}
Wire Electrical Discharge Machining (WEPSPDM) is utilizedin industries to manufacture components of conductive strong metal with complicated shape, greater tolerance and precision. A review of the literature exposes that most of the research work has been intended for towards the optimization of WEDM operation and modeling of the process. Conventional wire electrode has been developed to a brass wire from a copper wire and finally to zinc coated wire on the brass, steel or copper wire core, by which more advanced WEDM, is realized in terms of better machining speed and accuracy. To examine the parameters likePeak Current $\left(I_{p}\right)$, Time of Pulse ON $\left(T_{\text {on }}\right)$, Time of Pulse OFF ( $\left.T_{\text {off }}\right)$, etc. by the optimization of WEDM operation and modeling of the process during micro slit machining. Analyzed the results and optimize the process parameter conditions for maximum MRR ( $\mathrm{g} / \mathrm{min})$, and surface roughness based on Taguchi's Methodology. The ANOVA analysis indicates the significant factors for maximization of MRR, improvement of Surface Roughness and regression analysis. By the research work, it has been concluded that the MRR reduces with raise in Time of Pulse OFF $\left(T_{\text {off }}\right)$ and Set Voltage of spark gap (SV) besides Material Removal Rate (MRR) increases with escalating in Time of Pulse ON ( $\left.T_{\text {on }}\right)$ and PC $\left(I_{P}\right)$.
\end{abstract}

Key Words: WEDM, MRR, ANOVA,DOE, EDM

\section{INTRODUCTION}

In Wire Electric Discharge Machining (WEDM) process the quality of product is always concerned by its procedural parameters such as wire feed, peak current time, time of pulse ON, time of pulse OFF etc. At past decennaries, several research seekers were deeply go through the tested parameters. In current scenario, numerous seekers were specifically using Design of Experiment (DOE) for such kind of studies and identifies the finest factors which influences the obtained result. One simple work piece arrangement was used in this study and DOE was enforced to discover the best optimal input parameter value that alters the outcome result for specimen of WEDM. There was difficulty to pick out suitable approach for designing experiments because of enormous complexity in DOE. It was exposed through literature review that DOE founded by Taguchi method was previously utilized by many seekers and present study is also applying Taguchi method.

Revised Manuscript Received on August 27, 2020.

* Correspondence Author

Dr. Pankaj Sharma*, Department of Mechanical Engineering, JECRC University, Jaipur (Rajasthan), India. E-mail: hod.mechanical@jecrcu.edu.in

Dr. M. P. Singh, Department of Mechanical Engineering, JECRC University, Jaipur (Rajasthan), India. E-mail: mssinghmpsingh@gmail.com

(C) The Authors. Published by Blue Eyes Intelligence Engineering and Sciences Publication (BEIESP). This is an open access article under the CC BY-NC-ND license (http://creativecommons.org/licenses/by-nc-nd/4.0/)
Investigational complications plays a very important function for formulating DOE experiments. Table 1.1 shows the summary chart of four factors \& four levels and Table1.2 shows the L9 orthogonal arrays.

1. Using MINITA

Table 1.1: Summary chart of Factors and Levels

\begin{tabular}{|c|c|c|c|c|}
\hline \multirow{4}{*}{ Levels } & \multicolumn{4}{|c|}{ Factors } \\
\cline { 2 - 5 } & $\begin{array}{c}\text { Peak } \\
\text { Current } \\
\left(\boldsymbol{I}_{\boldsymbol{P}}\right) \\
(\text { Ampere) }\end{array}$ & $\begin{array}{c}\text { Time of } \\
\text { Pulse ON } \\
\left(\boldsymbol{T}_{\text {on }}\right) \\
(\boldsymbol{\mu})\end{array}$ & $\begin{array}{c}\text { Time of } \\
\text { Pulse OFF } \\
\left.\mathbf{(}_{\text {off }}\right) \\
(\boldsymbol{\mu s})\end{array}$ & $\begin{array}{c}\text { Feed } \\
\text { Rate } \\
(\mathbf{m} / \\
\mathbf{m i n})\end{array}$ \\
\hline 1 & 6 & 0.7 & 4 & 5 \\
\hline 2 & 7 & 0.9 & 5 & 7 \\
\hline 3 & 8 & 1.1 & 6 & 9 \\
\hline
\end{tabular}

2. Orthogonal Array

Table 1.2: L9 Orthogonal Arrays

\begin{tabular}{|c|c|c|c|c|}
\hline $\begin{array}{c}\text { S. } \\
\text { No. }\end{array}$ & $\begin{array}{c}\text { Peak } \\
\text { Current }\left(\boldsymbol{I}_{\boldsymbol{P}}\right) \\
(\text { Ampere) }\end{array}$ & $\begin{array}{c}\text { Time of } \\
\text { Pulse ON } \\
\left(\boldsymbol{T}_{\boldsymbol{o n}}\right)(\boldsymbol{\mu s})\end{array}$ & $\begin{array}{c}\text { Time of } \\
\text { Pulse OFF } \\
\left(\boldsymbol{T}_{\text {off }}\right)(\boldsymbol{\mu s})\end{array}$ & $\begin{array}{c}\text { Feed } \\
\text { Rate } \\
(\mathbf{m} / \mathbf{m i n})\end{array}$ \\
\hline 1 & 6 & 0.7 & 4 & 5 \\
\hline 2 & 6 & 0.9 & 5 & 7 \\
\hline 3 & 6 & 1.1 & 6 & 9 \\
\hline 4 & 7 & 0.7 & 5 & 9 \\
\hline 5 & 7 & 0.9 & 6 & 5 \\
\hline 6 & 7 & 1.1 & 4 & 7 \\
\hline 7 & 8 & 0.7 & 6 & 7 \\
\hline 8 & 8 & 0.9 & 4 & 9 \\
\hline 9 & 8 & 1.1 & 5 & 5 \\
\hline
\end{tabular}

\section{DATA ANALYSIS AND DISCUSSION}

WEDM process was experimentally solved in this study for wire cutting of using Regression Analysis (ANOVA) \&Design of Experiment (DOE) were utilized further to get equations. DOE tables were discussed. Main responses from this study were following, which discussed. As discussed, feed backare essential prophecy for quality of product. For finding the almost essential critical factors and their feedback on present study, firstly, ANOVA was used in present investigation and discussed further in pursuing article.

This investigation uses Minitab software for Regression Analysis \& ANOVA. Table 2.1 represents the four factors \& four level. 
Table2.1: Summary Table of four Factors and four Levels

\begin{tabular}{|c|c|c|c|c|}
\hline \multirow{4}{*}{ Levels } & \multicolumn{4}{|c|}{ Factors } \\
\cline { 2 - 5 } & $\begin{array}{c}\text { Peak } \\
\text { Current } \\
\left(\boldsymbol{I}_{\boldsymbol{P}}\right) \\
(\text { Ampere })\end{array}$ & $\begin{array}{c}\text { Time of } \\
\text { Pulse } \mathbf{O N} \\
\left(\boldsymbol{T}_{\boldsymbol{~}}\right) \\
(\boldsymbol{\mu})\end{array}$ & $\begin{array}{c}\text { Time of Pulse } \\
\mathbf{O F F}\left(\boldsymbol{T}_{\text {off }}\right) \\
(\boldsymbol{\mu s})\end{array}$ & $\begin{array}{c}\text { Feed } \\
\text { Rate } \\
(\mathbf{m} / \mathbf{m i n})\end{array}$ \\
\hline 1 & 6 & 0.7 & 4 & 5 \\
\hline 2 & 7 & 0.9 & 5 & 7 \\
\hline 3 & 8 & 1.1 & 6 & 9 \\
\hline
\end{tabular}

Unit: Peak Current

Time of Pulse ON
Time of Pulse OFF
Wire Feed Rate
A (Ampere)

$\mu \mathrm{s}$

$\mu \mathrm{s}$

$\mathrm{m} / \mathrm{min}$.

\subsection{Design of Experiment Analysis (Taguchi Method)}

Here,preference for Taguchi method was considered to resolve the impact of MRR and surface roughness due to four process parameters used as input parameters. The experimental value of MRR and surface roughness are shown in table 2.2.

Table2.2: Summary of Orthogonal array

\begin{tabular}{|c|c|c|c|c|c|c|c|}
\hline $\begin{array}{c}\text { S. } \\
\text { No. }\end{array}$ & $\begin{array}{c}\text { Peak } \\
\text { Current } \\
\left(I_{P}\right) \\
\text { (Ampere) }\end{array}$ & $\begin{array}{c}\text { Time } \\
\text { of } \\
\text { Pulse } \\
\text { ON } \\
\left(T_{o n}\right) \\
(\mu \mathrm{s})\end{array}$ & $\begin{array}{c}\text { Time } \\
\text { of } \\
\text { Pulse } \\
\text { OFF } \\
\left(T_{\text {off }}\right) \\
(\mu \mathrm{s})\end{array}$ & $\begin{array}{l}\text { Feed } \\
\text { Rate } \\
(\mathbf{m} / \\
\text { min) }\end{array}$ & $\begin{array}{l}\text { Machinin } \\
\text { g } \\
\text { rate } \\
(\mathrm{mm} / \mathrm{min})\end{array}$ & $\begin{array}{c}\text { Surface } \\
\text { roughness } \\
(\mu \mathrm{m})\end{array}$ & $\begin{array}{l}\text { MRR } \\
\text { g/min }\end{array}$ \\
\hline 1 & 6 & 0.7 & 4 & 5 & 0.520 & 2.446 & 0.026536 \\
\hline 2 & 6 & 0.9 & 5 & 7 & 0.739 & 2.694 & 0.012776 \\
\hline 3 & 6 & 1.1 & 6 & 9 & 0.958 & 2.943 & 0.013759 \\
\hline 4 & 7 & 0.7 & 5 & 9 & 0.505 & 2.440 & 0.02457 \\
\hline 5 & 7 & 0.9 & 6 & 5 & 0.726 & 2.675 & 0.012187 \\
\hline 6 & 7 & 1.1 & 4 & 7 & 0.992 & 2.976 & 0.021622 \\
\hline 7 & 8 & 0.7 & 6 & 7 & 0.493 & 2.420 & 0.055528 \\
\hline 8 & 8 & 0.9 & 4 & 9 & 0.759 & 2.721 & 0.023587 \\
\hline 9 & 8 & 1.1 & 5 & 5 & 0.980 & 2.956 & 0.028501 \\
\hline
\end{tabular}

For finding the impact on quality of product, $\mathrm{S} / \mathrm{N}$ ratio was considered easiest mechanism to guess the changing impact on factors accordingly with their levels. In present investigation "larger is better" and "littler is better", both was adopted as quality signaling considering $\mathrm{S} / \mathrm{N}$ ratio, further, this happens because of WEDM process.

Table2.3: (a) Response table for $\mathrm{S} / \mathrm{N}$ ratio (larger is better) for MRR

\begin{tabular}{|c|c|c|c|c|}
\hline Levels & $\begin{array}{c}\text { Peak } \\
\text { Current }\end{array}$ & $\begin{array}{c}\text { Time of } \\
\text { Pulse ON }\end{array}$ & $\begin{array}{c}\text { Time of } \\
\text { Pulse OFF }\end{array}$ & $\begin{array}{c}\text { Feed } \\
\text { Rate }\end{array}$ \\
\hline 1 & -35.54 & -29.61 & -32.46 & -33.57 \\
\hline 2 & -34.59 & -36.23 & -33.66 & -32.09 \\
\hline 3 & -29.52 & -33.81 & -33.54 & -33.99 \\
\hline Delta & 6.02 & 6.63 & 1.20 & 1.89 \\
\hline Rank & $\mathbf{2}$ & $\mathbf{1}$ & $\mathbf{4}$ & $\mathbf{3}$ \\
\hline
\end{tabular}

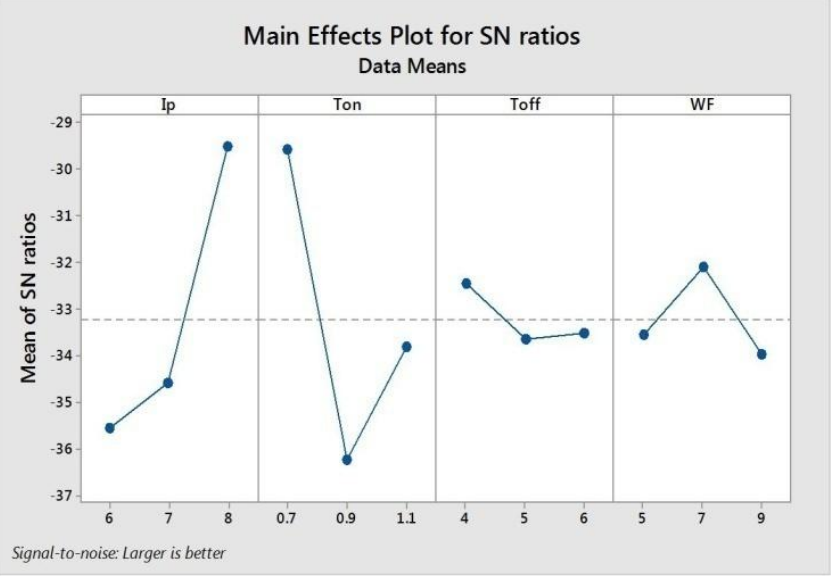

Fig. 2.1 (a) $\mathrm{S} / \mathrm{N}$ ratio (larger is better) for MRR

The response tables for MRR were shown in Table 2.3(a) larger is better and Table 2.3 (b) littler is better and Table 2.4 respectively for $\mathrm{S} / \mathrm{N}$ ratio.

Table 2.3 (b) Response table for $\mathrm{S} / \mathrm{N}$ ratio (littler is better) for surface roughness

\begin{tabular}{|c|c|c|c|c|}
\hline Levels & $\begin{array}{c}\text { Peak } \\
\text { Current }\end{array}$ & $\begin{array}{c}\text { Time of } \\
\text { Pulse ON }\end{array}$ & $\begin{array}{c}\text { Time of } \\
\text { Pulse OFF }\end{array}$ & $\begin{array}{c}\text { Feed } \\
\text { Rate }\end{array}$ \\
\hline 1 & -8.584 & -7.730 & -8.644 & -8.576 \\
\hline 2 & -8.588 & -8.617 & -8.590 & -5.586 \\
\hline 3 & -8.596 & -9.421 & -8.532 & -8.606 \\
\hline Delta & 0.011 & 1.691 & 0.114 & 0.029 \\
\hline Rank & $\mathbf{4}$ & $\mathbf{1}$ & $\mathbf{2}$ & $\mathbf{3}$ \\
\hline
\end{tabular}

Response table for surface roughness was show that input Parameter pulse on time was most critical responsible parameter for roughness for both type of $\mathrm{S} / \mathrm{N}$ ratio. Stationed on $\mathrm{S} / \mathrm{N}$ ratio response table, ranks was allotted to locate value of factors for this research. Most critical parameter was pulse on time whereas less important parameter was pulse off time for MRR and peak current for surface roughness. Response figures for both combinations were shown below respectively (see figure 2.1(a) and figure 2.1(b))

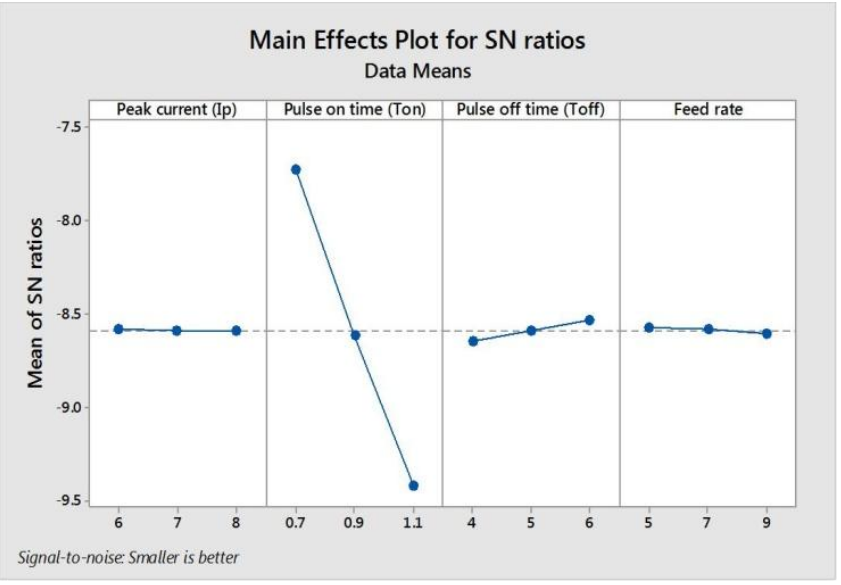

Fig.2.1 (b) S/N ratio (smaller is better) for surface roughness 
Foremost set of sequence \&collected parametric quantities was determined by choosing different levels together with higher parametric quantity of $\mathrm{S} / \mathrm{N}$ ratio from tables or graph and color in tables by graphite color.

Input results and input parameters were nicely synchronized by $\mathrm{S} / \mathrm{N}$ ratio and response figure based on means were shown in figure 2.2 \& table 2.4 which implementing affirmation means based study for present research purpose.

Table 2.4 Response table for means for MRR

\begin{tabular}{|c|c|c|c|c|}
\hline Levels & $\begin{array}{c}\text { Peak } \\
\text { Current }\end{array}$ & $\begin{array}{c}\text { Time of } \\
\text { Pulse ON }\end{array}$ & $\begin{array}{c}\text { Time of } \\
\text { Pulse OFF }\end{array}$ & $\begin{array}{c}\text { Feed } \\
\text { Rate }\end{array}$ \\
\hline 1 & 0.01769 & 0.03554 & 0.02391 & 0.02241 \\
\hline 2 & 0.01946 & 0.01618 & 0.02195 & 0.02998 \\
\hline 3 & 0.03587 & 0.02129 & 0.02716 & 0.02064 \\
\hline Delta & 0.01818 & 0.01936 & 0.00521 & 0.00934 \\
\hline Rank & $\mathbf{2}$ & $\mathbf{1}$ & $\mathbf{4}$ & $\mathbf{3}$ \\
\hline
\end{tabular}

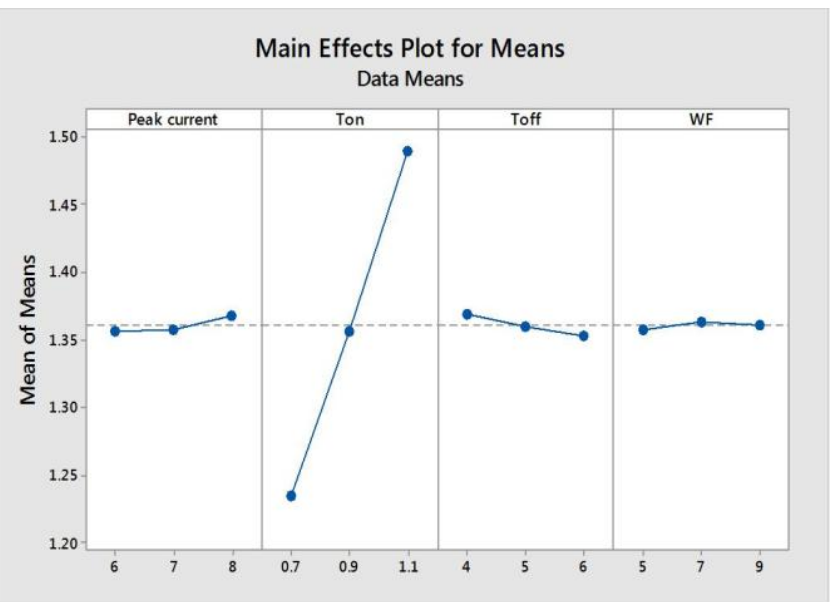

Fig. 2.2 Means for MRR

From figure 2.2 and table 2.4 shows that most important parameter was pulse $\mathrm{ON}$ time and this parametric value was clearly managing the changes in responses of present study.

The nicely prepared pairs of parameters will concluded by choosing the various high mean values levelsfrom figure 2.2 and table 2.4 (graphite color).

After Taguchi analysis it was clear that pulse on time was responsible for MRR and surface roughness during experimental work of this study and this was verified by ANOVA analysis which was discussed in next section.

\subsection{ANOVA Investigation}

Table 2.5 is showing the results of computed ANOVA on specimen. Comparison between residual variance and model variance was performed by F-Test. Here, value of $\mathrm{F}$ was measured by division of MMS by RMS values and if calculated value of $\mathrm{F}$ is one then both the variances were same and if calculated value of $\mathrm{F}$ is larger then it is the foremost way to determine the critical I/p parameters.

Table 2.5 ANOVA results for strain rate for MRR

\begin{tabular}{|l|c|c|c|c|c|}
\multicolumn{7}{c}{ Source } & \multicolumn{1}{c}{ D F $_{\text {F }}$ Adj. SS } & Adj. MS & F-Value & $\begin{array}{c}\text { P- } \\
\text { Value }\end{array}$ \\
\hline Regression & 4 & .000821 & .00025 & 1.43 & .369 \\
\hline $\mathrm{I}_{\mathrm{p}}$ & 1 & .000496 & .000496 & 2.12 & .137 \\
\hline
\end{tabular}

\begin{tabular}{|l|c|c|c|c|c|}
\hline $\mathrm{T}_{\text {on }}$ & 1 & .000305 & .000305 & 3.45 & .019 \\
\hline $\mathrm{T}_{\text {off }}$ & 1 & .000016 & .000016 & .11 & .757 \\
\hline WF & 1 & .000005 & .000005 & .03 & .865 \\
\hline Error & 4 & .000575 & .000144 & & \\
\hline Total & 8 & .001396 & & & \\
\hline
\end{tabular}

This is clear from literature review that value of $\mathrm{P} \leq 0.5$ makes significant impact on responses of regression model. Table 2.5 gives essential outcome that value of $\mathrm{F} \geq 1$ for $\mathrm{RM}$ whereas value of $\mathrm{P} \leq 0.019$, which implies that whole variables were important.

Model values of P \& F were 0.019 \& 3.15 for MRR and indicates that $\mathrm{P}$ had significant impact on MRR in WEDM and this makes not so improved conformity with MRR.

\subsection{Regression Equations}

Present study were also developed regression equations for MRR output parameter based on Taguchi.

\section{Regression Equation for MRR}

MRR $=-0.0122+0.00909$ Peak current- 0.0356pulse on time+ 0.00162pulse off

Correlation coefficient

Correlation co-efficient $\left(\boldsymbol{R}^{2}\right)$

\begin{tabular}{|c|c|c|c|}
\hline $\mathbf{S}$ & $\mathbf{R}^{2}$ & $\mathbf{R}^{2}$ (adj) & $\mathbf{R}^{2}$ (pred) \\
\hline .120128 & $87.87 \%$ & $76.63 \%$ & $68.05 \%$ \\
\hline
\end{tabular}

Correlation coefficients for this equation were approach 90\% more liner accuracy and prediction wasapprox 70\% which was also good for future application of equations. Table 2.6 shows the prediction table of model equation and figure 2.3 shows the difference between the experimental and predictor result.

Table 2.6 predication Table of model equation

\begin{tabular}{|c|c|c|c|c|c|c|c|}
\hline $\begin{array}{l}\text { S. } \\
\text { No }\end{array}$ & \begin{tabular}{|c} 
Peak \\
Current \\
$\mathrm{I}_{\mathrm{p}}$ \\
(Ampere)
\end{tabular} & $\begin{array}{c}\text { Time } \\
\text { of } \\
\text { Pulse } \\
\text { ON } \\
\text { T }_{\text {ON }} \\
(\mu s)\end{array}$ & $\begin{array}{c}\text { Time } \\
\text { of } \\
\text { Pulse } \\
\text { OFF } \\
\text { T }_{\text {OFF }} \\
(\mu s)\end{array}$ & $\begin{array}{c}\text { Feed } \\
\text { Rate } \\
\text { (meter/ } \\
\text { min) }\end{array}$ & $\begin{array}{c}\text { Experimental } \\
\text { MRR } \\
(\text { gram } / \text { min })\end{array}$ & $\begin{array}{c}\text { Predict } \\
\text { Value }\end{array}$ & Difference \\
\hline 1 & 6 & 0.7 & 4 & 5 & 0.0265 & 0.0216 & 0.0106 \\
\hline 2 & 6 & 0.9 & 5 & 7 & 0.0128 & 0.0152 & 0.0063 \\
\hline 3 & 6 & 1.1 & 6 & 9 & 0.0138 & 0.0089 & 0.0106 \\
\hline 4 & 7 & 0.7 & 5 & 9 & 0.0246 & 0.0306 & 0.0080 \\
\hline 5 & 7 & 0.9 & 6 & 5 & 0.0122 & 0.0268 & 0.0080 \\
\hline 6 & 7 & 1.1 & 4 & 7 & 0.0216 & 0.0156 & 0.0080 \\
\hline 7 & 8 & 0.7 & 6 & 7 & 0.0555 & 0.0422 & 0.0094 \\
\hline 8 & 8 & 0.9 & 4 & 9 & 0.0236 & 0.0309 & 0.0094 \\
\hline 9 & 8 & 1.1 & 5 & 5 & 0.0285 & 0.0272 & 0.0094 \\
\hline
\end{tabular}




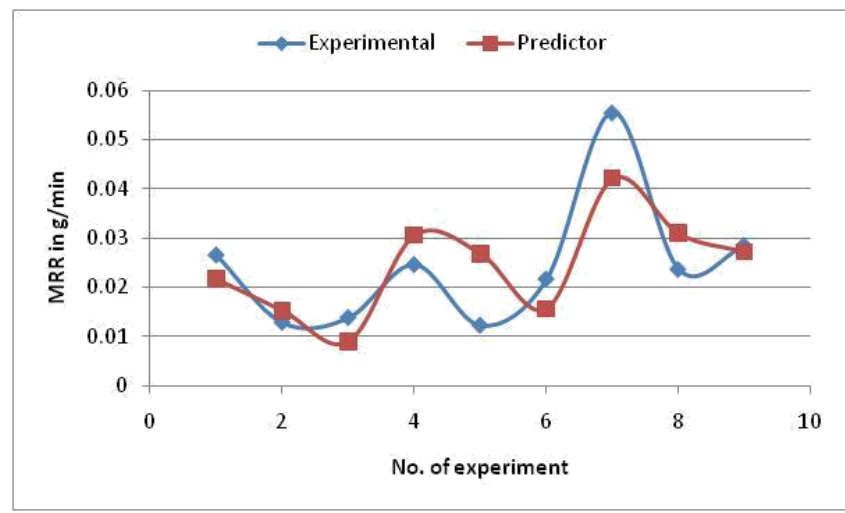

Fig. 2.3 Difference between the experimental and predictor result

\subsection{Photograph of experimental work-piece}

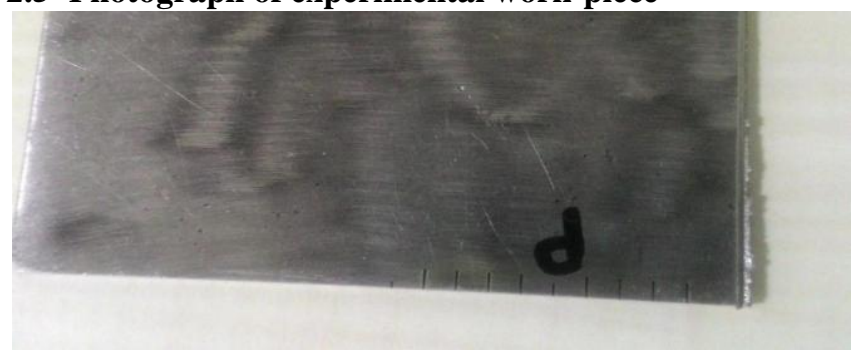

Fig 2.4 Experimental work piece

\section{SEM Micrographs of WEDM Surface}

Comparing the impact of brass wire during machining of specimen and analyzing the characteristics and surface integrity under Scanning Electron Microscopy (SEM). SEM examined the crater size, HAZ, roughness and recast layer depth for Nimonic alloy.
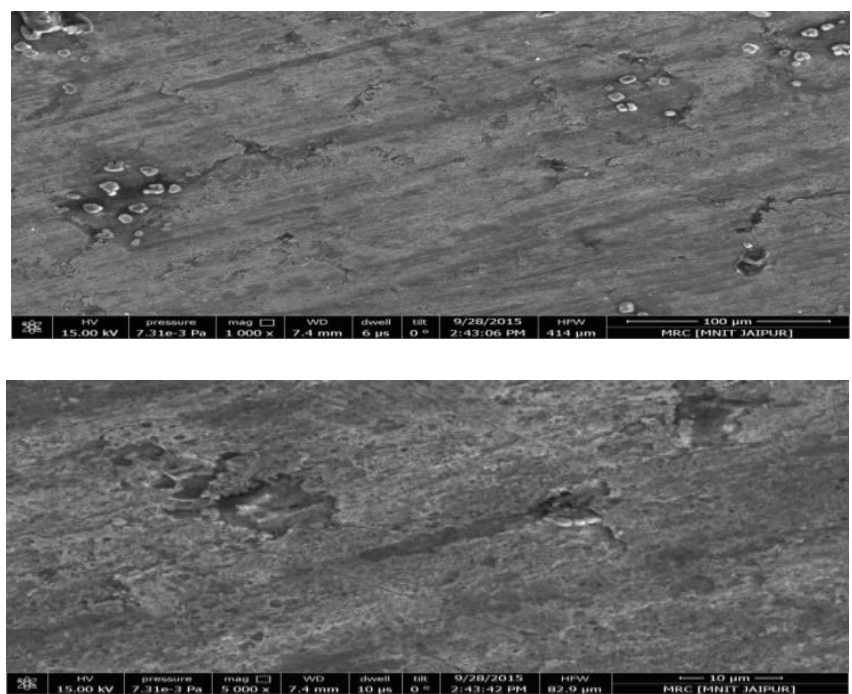

Fig 2.5 SEM image of WEDM surface

Figure 2.5 shows the images of SEM for WEDM surface and showed that HS brass wire shows a best surface finishing.

\section{CONCLUSION}

This study recapitulates the activity managed on processing of Nimonic 80A using WEDM. Nimonic 80A is moderately machined under WEDM.
1. The MRR reduces with raise in Time of pulse OFF $\left(\mathrm{T}_{\mathrm{OFF}}\right)$ \& Spark gap Voltage (SV) and increases with raise in Time of Pulse ON ( $\left.\mathrm{T}_{\mathrm{ON}}\right)$ \& Peak Current $\left(\mathrm{I}_{\mathrm{P}}\right)$.

2. The use of Nimonic 80A in WEDM for machining with brass wire enhances MRR. Less time is required for processing same amount of work piece material. Superior surface finish of machined work-piece and less WWR of wire is also obtained.

3. Increase in machining temperature of Nimonim is due to larger chemical reactivity and lesser thermal conductivity of Ti.

4. Wire breakage at the time of machining is directly effecting the surface roughness on sample and cutting speed of WEDM process.

5. The sample gains its highest performance due to high heat conductivity and electrical conductivity as well as negligible TS at high temperature and low melting temperature of parent metal.

6. The computercontrolled positioning system is continuously maintained the gap between specimen and wire ranging from $0.025-0.050 \mathrm{~mm}$.

7. In present study, larger is better and smaller is better were used as indicator for finding $\mathrm{S} / \mathrm{N}$ ratio because $\mathrm{S} / \mathrm{N}$ ratio is simplest procedure for predicting the impact of change in various factors.

8. After solving ANOVA, this was analyzed that highest value for $F$ test was good to search critical $I / p$ parameters.

9. Study suggest that all variables are significant because value tested value for $\mathrm{F}$ test are higher (table $5.8 \mathrm{~F}$ value was 3.45) than one and value of $P$ test are lesser (0.019) than one.

10. Time of Pulse ON for F and P were 3.45 \& 0.019 and shows that value of $\mathrm{P}$ was very less than 0.019 and this directly impact on MRR and WEDM cases.

\section{REFERENCES}

1. Amitava Mandala, Amit Rai Dixita, Alok Kumar Dasa\&NiladriMandalb, (2015),"Modeling and Optimization of Machining Nimonic C-263 Super Alloy Using Multi-Cut Strategy in WEDM" Defence Research and Development Laboratory, Kanchanbagh, Hyderabad, India.

2. Kumar, A., Kumar, V., Kumar, J., (2012). “An Investigation into Machining Characteristics Commercially Pure Titanium Using CNC WEDM" Applied Machines and Materials159, p. 56-68.

3. Antar, M.T., Soo, S.L., Aspinwall, D.K., Jones, D., Perez, R., (2011),"Productivity and Work Piece Surface Integrity when WEDM Aerospace Alloys Using Coated Wires", Procedia Engineering19, p. 38.

4. Xu, Y., Guo, X., Liu, Ch., (2011). "Study on Wire Breakage in WEDM by 3D Technology", Applied Mechanics and Materials4447, p. 1442-1448.

5. Ahmet Hascalyk, UlasCaydos. (2004), "Experimental study of wire electrical discharge machining of ASIS D5 tool steele, Journal of Materials Processing Technology, Vol.148, pp: 362-367.

6. AkgiinAlsaran. Ayhan C., Cafer C. and IhsanEfeoglu.(2004), "Optimization of coating parameters for duplex treated AISI 5140 Steel”, Journal of Materials Science andEngineering, Vol. A371, pp.141-148.

7. Ezugwu E.O., (2005), "Key improvements in the machining of difficult-to-cut aerospace alloys", International Journal of Machine Tools and Manufacture, Vol. 45, pp: 1353-1367.

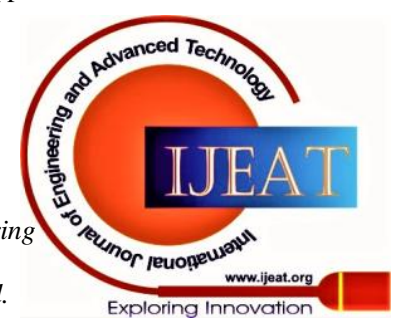


8. Ezugwa E. O, Bonney. J, Yamane. Y, (2003) "An overview of the machinability of aeroengine alloys", Jour. Of Mat. Proc. Tech, Vol 134, pp: 233-253.

9. Kanlayasiri K., Boonmung S., (2007)“Effects of WEDM machining variables on surface roughness of newly developed DC 53 die steel: Design of experiments and regression model", Journal of Materials Processing Technology, Vol. 192-193, pp: 459-464.

10. Kiyak M., ÇakirO,(2007) "Examination of machining parameters on surface roughness inEDM of tool steel", Journal of Materials Processing Technology, Vol. 191, pp: 141-144 .

11. Puertas I., Luis C.J., Álvarez L., (2004), "Analysis of the influence of EDM parameters on surface quality, MRR and EW of WC-Co", Journal of Materials Processing Technology, Vol. 153-154, pp 1026-1032.

12. Ramakrishnan R., Karunamoorthy L., (2008) "Modeling and multiresponse optimization of Inconel 718 on machining of CNC WEDM process", Journal of Materials ProcessingTechnology, Vol. 207, pp: 343-349.

13. Sarkar S., MitraS.,Bhattacharyya B., (2006)"Parametric optimization of wire electrical discharge machining of $\mathrm{M}$ titanium aluminide alloy through an artificial neuralnetwork model", International Journal of Advance Manufacturing Technology, Vol.27, pp: 501-508.

14. Traguchi. G, (1986), "Introduction to Quality Engineering Designing Quality Products and Processes", Asian Prod. Orgn, Tokyo.

15. Ezugwa.E O, Wang Z. M, Machado. A. R, (1999), "The machinability of Nickel-based alloys: A Review", Jour. Of Mat. Proc. Tech., Vol 86, pp: 01-16.

\section{AUTHOR PROFILE}

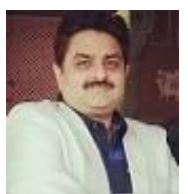

Dr. Pankaj Sharma is presently working as Professor \& Head (ME) in JECRC University,Jaipur.He has total 24 Year,s Experience of Teaching as Professor,Principal, Dean Academic and Academician in various Engineering Institutes. He didM.Tech. \& Ph.D. degree from MNIT Jaipur. He has published more than 20 research papers. Hehas been awarded by Vigyan Ratna award by AITMC in June 2013. He is Fellow Member of Indian Society of Mechanical Engineers and Member of editorialBoard of Journal of Automotive Mechanical and Aerospace Engineering Research.

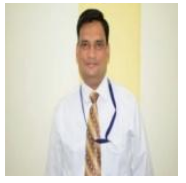

Dr. Mahendra Pratap Singh is a Professor in the Department of Mechanical Engineering at Jaipur Engineering College \&Research Centre, Jaipur, India. He was Selected for Kirchhoff ResearchAward-2015 in Mechanical Engineering by IASR. He has published two patents and 32 papers in Scopus journals and reputed conference proceedings. He has authored four books withLambert Academic publishing and Ashirwad Publisher 